\title{
System Approach for Strategic Planning in Transport
}

\author{
B. Horváth, B. Gaál \\ Széchenyi István University, Department of Transport \\ Egyetem tér 1., 9026 Győr, Hungary \\ Phone: +36 96503494 \\ e-mail: gaalb@sze.hu
}

\begin{abstract}
The paper gives an overview on the current status of the connection between city and transport. After a short theoretical introduction on the effect of different city development strategies it shows the importance of transport in the life of a settlement. Through international best practice, there are some good examples on the holistic planning of a city.
\end{abstract}

Keywords: transport system planning, urban planning, mobility management

\section{Introduction}

István Széchenyi is esteemed as the founder of the Hungarian Academy of Sciences or the builder of Chain Bridge. However, in the field of transportation his biggest contribution was the creation of the first transport policy. [1] One of the most important and relevant statement of the policy was the following: "Transportation is not constituted as the core of the state, but it has the same effect as the veins in a living body" and "...there is no such a sector in our public and private economy, which is not affected [by transportation]..." [2]. Nowadays, in Hungary, these two statements have been forgotten or at least overshadowed by other factors. Sadly, it negatively affects the livable, sustainable city life.

This article, through some ideas and examples, would like to draw attention to the inseparability of the city and its transportation system. During the planning of cities we (should) consider the effects and demands of the developments.

In this article we use the word transportation in its broadest meaning it includes transportation of people and goods, public and individual, and motorized and nonmotorized transportation. System approach also means we do not emphasize certain solutions rather we seek equilibrium in the multitude of solutions. The importance of the topic is indicated by the $7^{\text {th }}$ consecutive victory of Vienna in the quality of living rankings in 2016 which victory was partially achieved thanks to its transport system. 


\section{City and transportation}

Széchenyi had discovered already in the $19^{\text {th }}$ century the transport economics principle that transport demand is a derived demand, that is, it is generated by the spatial separation of socioeconomic processes. Subsequently, the problems of transportation systems cannot be handled by only the tools of transport planning or traffic management. Csaba Orosz [3] had similar concept when he said that the best (cheapest) trip is which does not happen. Hörcher [3] approached this theory from economics point of view.

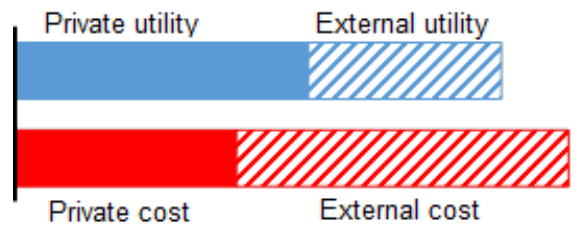

Figure 1.: The real and putative utilities and costs of trips [4]

He expressively defined the economic axiom that a trip results in negative utility for passengers (Fig. 1.). If the cost of a journey is less than the utility of the reached activity the journey will be realized. For example, when one is looking for a job he will ponder on the distance from where commuting is still worth. If the transportation system, regulatory environment and the structure of the city is such that one has to travel a lot, but he can do it cheaper (as cheaply we meant the complex of price, time and other factors) then one will do the journey. However, this journey costs not only him, but also society as it can be seen in figure 1 . This means when an employee regularly takes long rides to the workplace not only he inflicts cost to himself but also for society. If we encumber travelling, for example by charging the traveller for fully or partially the real cost of travel then this could force the change of travel behaviour (for example, they move near to their workplace or switch to public transport - if there is any). This simple example also reveals that the first step in properly managing the transport system is the examination of transport demand (why people travel?) and the planning or development of the transport system as a technological system only could follow this phase.

Transport demand depends on different places has to be reached by the user and their spatial distribution as most transport models consider it in their trip generation phase. Traditionally simple linear correspondence can be demonstrated between the number of inhabitants, schoolchildren, jobs, shops of an area and departing/arriving trips.

\section{Transportation effects of districts and facilities}

Nowadays, in the age of mobility demand for transport rising like never before. In the light of this fact, it is worth considering the development of districts or facilities. When we speak about the development of districts we have to separate the development of neighbourhoods and economic zones. In our days, economic zones are mainly implemented as mono-functional greenfield or brownfield investments. The primary aspect of the location choice is the transportation needs of raw materials and/or (semi)finished products. What about the employees? How can they reach their 
workplace? Is this question emerged during the designation of development areas? Why is it important? There are two answers: time and money. While the local authorities battle for investors by designating development areas at the same time it is a serious problem for them to finance the public transport lines of these areas. After all, only few, big employer could allow itself the organized transport of employees. Is there anyone who considers during the development process the financing of future public transport's operation?

It is may be demagogic to say that move dwellings closer to industrial areas as no one would like to live in the vicinity of one. However, it is highly important to take into account this - in the time of the planning process - latent travel demand.

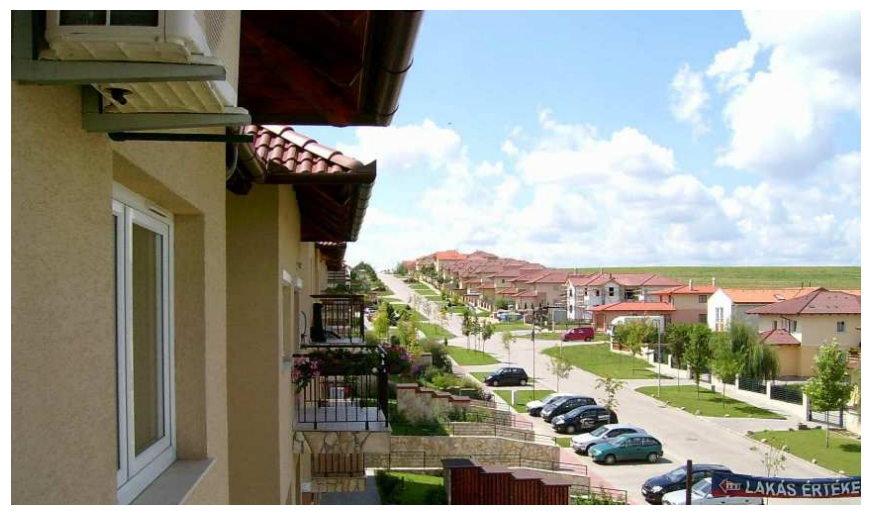

Figure 2.: Typical subdivision (Source: maps.google.hu)

Other similar problems occur with subdivisions. In this case the main question is the evaluation of future traffic between the development area and other parts of the city. Did anyone examine the trip generation effect of the new quarters in the master development plan? Did it occur to anybody that not only public utilities, but road network also have to be able to support the new population and its activity? As we already mentioned it is the age of mobility and these subdivisions function like classic commuter towns. Furthermore, because of the low intensity of built-up it generally lacks efficient public transport system.

As a result, a 10 apartment complex with an average of 30 residents (given the average 1.5 people per car) means 20 cars. With ten such a building it is 200 new cars participating in traffic. At night these cars need parking place also. In Hungary OTÉK (Decree No. 253 of 1997 (XII. 20.) of the Government on national urban development and building requirements) determines the minimal parking place per households, which is exactly one. Some local government raises the minimal parking place to 1.5 per household, but in our little example, there is another five which remains on the road (assuming that everyone bought the parking lot marked out for him and uses it). Residential parking lots are under-proportioned and as they have been sold separately from apartments (and many do not buy them) they tend to be empty and cars of the residents are stored on the road surface. 
Although this could lead to the higher usage of public transport, but the system because of the abovementioned inefficiency - mostly had not been established in due form to compete with private transport.

Another kind of problem occurs when the intensity of built-up is high, but during the planning process public transportation was not taking into consideration (lack of stops and turns, non-passable roads).

It is important to mention other high traffic attraction facilities like malls or stadiums. They have a dual demand as transport have to serve both the facilities (shops) and the visitors and not only with parking lots.

To summarize this train of thoughts it is important to state that in order to a development fully functions its accessibility is also decisive, but in Hungary only parking is regulated by OTÉK [5].

\section{Transport demand and spatial structure}

Modern society based on mobility and transport possibilities. Transport demand originates from the spatial division of economic activities (spatial division of labour). Earlier in history every function (housing, workplace, service) were present in a very limited space. In modern times they are divided by larger and larger distances. This is originates from the era of the industrial revolution. At that time earlier manufactures gave up their place to big factories. These factories had a considerable environmental impact (noise, air pollution) thus dwellings built up not next but near to them. This structure projected the posterior homogeneous districts, but due to low distances traffic problems were small-scaled.

By evolution of technology, especially transport technology, people could take longer and longer journeys, regularly and dependably. Thus, concentrated industrial areas and living quarters situated increasingly further away from each other generating more and more transport needs. At the same time, the concentration of workplaces and dwellings resulted in a relatively homogeneous travel structure which could be satisfied by public transport services. Besides residential areas contained the necessary place of services (day-nursery, kindergarten, school, pharmacy, market, stores, etc.) thus in everyday life usage of the transport system other than the commute to work was not necessary. Contrarily, at present subdivisions prevail which on one hand do not offer these primary functions, on the other hand, they do not get sufficient public transport service. Reasons could be the lack of critical mass or hiatus of plans concerning transportation needs. Because all of this transport acts the part of infrastructure, meaning we build roads in order to let population access services they cannot get on the spot. The question is which solution is more efficient in the long run.

\section{Planning examples}

Thereafter, we would like to present some good practice examples in the field of transport-aware urban planning.

Transit oriented development (TOD) is a desirable possibility for rapidly growing urban areas. The conception is simple: let's make a self-sufficient town or district with a 
relatively dense built-up of housing, services and workplaces around high capacity stations of transport lines (mostly train or light train). Combined with a pedestrian friendly environment this kind of development could lessen private car usage and motorization.

Bogota, Columbia, started its BRT (Bus Rapid System) project at the end of the nineties. Its precursor was Curitiba, Brazil. Opposite to the Brazilian practice the management of Bogota concentrated on the development not only the city centre and the BRT system. Of course they implemented the separate bus lanes on main roads with attractive stops. At the same time they also implemented a pedestrian and cycling infrastructure development connected to the system even in the poor districts. This made the new system easily accessible even by foot. After the inauguration, the system was a huge success. The number of accidents was lowered, pollution decreased, one-tenth of the users chose the Transmilenio (this is the name of the system) over their cars, even criminal statistics changed for the better. Despite this success Transmilenio have not had such a land use altering effect like the one in Curitiba, albeit along the lines services met more favourable terms and opportunities and real estate prices rose. Of course, many factors contributed to the success of the change of the transport system. The Transmilenio system was well-planned ( $\mathrm{P}+\mathrm{R}$ at peripheral stops, high accessibility of stops by foot and bike, joint infrastructure) but the cycling infrastructure had a more astounding impact. More than $200 \mathrm{~km}$ dedicated cycling path was built and the share of cycling rose from $0,9 \%$ over $5 \%$. Popularity of cycling was influenced by favourable conditions like relatively flat surface (Bogota is situated in a valley in the Andes), mild weather all year round and mixed land use which caused the under $10 \mathrm{~km}$ average travel length. Success was strengthened by further actions like car-free days, road closings on Sundays, car usage restrictions, etc.

The mature form of TOD is present in Europe, its cradle. Development plans of Copenhagen ("Finger Plan") or Stockholm ("Planetary Cluster Plan") are early representatives.
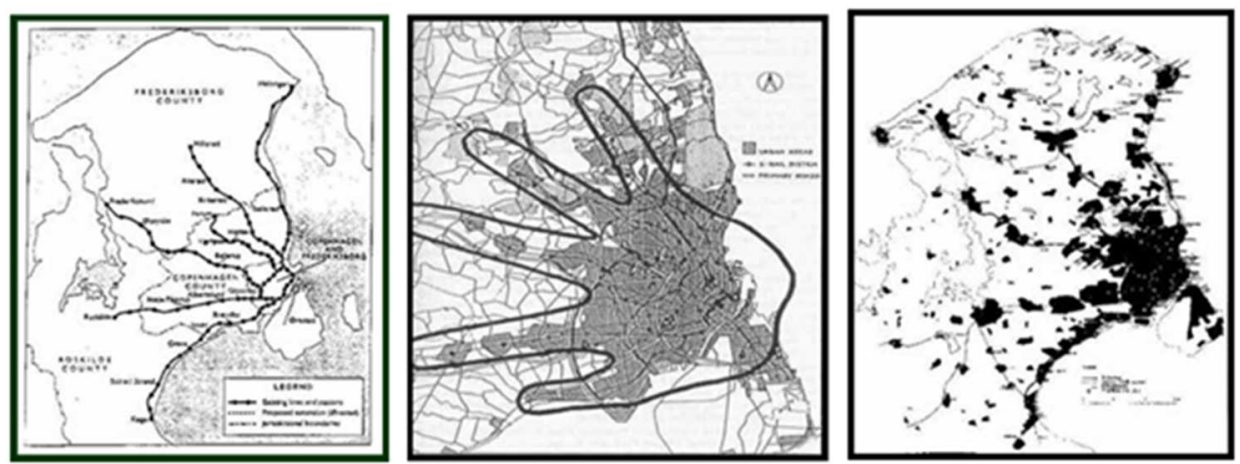

Figure 3.: The realization of the "Finger Plan" in case of Copenhagen [6]

Such a suburban development of Stockholm became an international model [7] primarily as a green city[8]. Hammarby Sjöstad was an abandoned industrial area. After Sweden lost in the tender for 2004 summer Olympics it was developed as a brown-field investment. Hammarby is situated only $3 \mathrm{~km}$ from the downtown of Stockholm. It offers densely built-up, but attractive environment (nearly 20.000 inhabitants). During the 
planning process many viewpoints were taken into consideration like mixed land use, high level accessibility and attractive streets for pedestrians and cyclists. Most services were placed along the main transport axis, other shops and restaurants were scattered in the residential areas. On the whole 30 percent of the suburb is industrial and business area. Despite environmental friendliness car infrastructure is also well-developed. There is 0.7 parking places per flat and the southern motorway is next to the suburb. To counteract these effects the city has a good public transport connection with Stockholm through bus lines, high capacity tram and ferries. Above all, there is a car-sharing system providing cars for members. Thanks to all of these in 2010 the modal-split was the following: $52 \%$ of the trips were made by public transport, $27 \%$ on foot or by bike and only $21 \%$ by car.

Freiburg had a similar model project [9] [10]. Vauban (5.000 inhabitants), which is also $3 \mathrm{~km}$ away from the city centre, was built as a pilot program for modern, energy-efficient, green cities. The district was built in such a fashion that the workplaces and services could be reached on foot or by bike. It was also the main consideration during shaping the roads. Car traffic was encumbered by hamstring the transit and speed-limits $(30 \mathrm{~km} / \mathrm{h}$ on the main road and $5 \mathrm{~km} / \mathrm{h}$ on other roads). Bus service reaches only the edges of the district, while the tram line connecting the district to the downtown is in the main axis. Further aggravating for car owners is the strict parking regulation. Although the district is not outright car-free zone (or according to [11] it could be considered as a type of car-free development) and residents can own automobiles, at the same time they must park them in communal parking lots situated on the edges of the district. Residents have to buy their parking space and also pay further regular fee for it. While results are considered good (16\% of the trips made by car, $19 \%$ by public transport, $64 \%$ on foot or by bike - which is better than the Freiburg average) yet problems arise in the run. Most people support the idea of car-free, liveable environment as long as they do not have to abandon theirs. Many inhabitants tried to avoid the high fees by disavowing or un-admitting their cars parking those in the surrounding districts aggravating their situation.

The project of Vauban especially well-documented from a transportation point of view, see [12][13][14][15].

Media City, Manchester, was a phase of one of the largest urban rehabilitation project in England. In place of old docklands new, attractive business and cultural centre has been built to revitalize the run-down part of the city. Media City is the example of joint development of urban and transport concepts. Early in the preparation stage it was clear that recent links will not cope with the anticipated extend of traffic, thus, in parallel, their development is much needed. Investors and the regional development agency gave 25 million pounds to local transportation association to improve transport connections. As a result a new spur from the existing tram line was built and new trams were purchased. It made possible the frequent service to the centre of Manchester. On the other hand tram line also ensured the accessibility of residential areas. Provident development was especially important for the local transportation association as their business is fully commercialized, they do not get subvention and have to finance and invest from their own profit.

However, new tram line alone was not sufficient. The neighbouring district, Salford, was approachable only by car, thus the parties concerned agreed upon starting a new bus 
line. As there is no subvention in the UK for these services, but it has been deemed necessary the local government and the university agreed to sponsor the line for 5 years (when it is expected to be self-supporting). Beside public transport non-motorized forms was also focused on. Attractive pedestrian and cyclist infrastructure was important contributors to the success (pedestrian bridges over the docks, $\mathrm{B}+\mathrm{R}$ facilities). Investors were motivated to build them by the regional development council as they give their consent to continue the development only if investors possess such a plan which guarantee that $45 \%$ of the trips are made by other modes than a car.

Other local examples are intermodal centres. These are mainly terminals, places with excellent connection. They are frequently situated in run-down downtown areas where they can be the centre of renewal. During the renewing process these places previously with solely interchange function became multifunctional communal areas. In Hungary, similar albeit unsuccessful attempts were KÖKI terminal and West End. The fail of these initiatives were because while situated next to train terminals, they were not an organic whole and their function did not strengthen each other.

\section{Conclusions}

As a conclusion it can be stated that transportation should have to make a greater role in regional and urban development. Planners should be aware the fact, that transportation is a derived phenomenon which is shaped by the development. If we mix the functions within an area, or link the homogeneous areas by adequate links, less and easier to handle transport demand will appear. This means more liveable environment, clear air and less social externalises.

Our settlements could be made sustainable and desirable in the long run only by the triad of good regulatory environment, transport-oriented regional development and transport development aiming for healthy equilibrium of modal split.

\section{References}

[1] The $1848 \mathrm{XXX}$. On the tasks of the Minister for the vehicles (in Hungarian)

[2] Széchenyi I: Proposal for settlement of the Hungarian transport case, 1848 (in Hungarian)

[3] Orosz Cs: The possibilities of influencing travel mode choice in Budapest, Városi közlekedés 1993/2. pp. 88-97 (in Hungarian)

[4] Hörcher D: The optimal congestion: pricing and capacity management in public transport, in Közlekedéstudományi Konferencia Győr 2016. Universitas Kft., pp. 66-87 (in Hungarian)

[5] 253/1997. (XII. 20.) Government Decree, national town planning and building requirements (in Hunagrian)

[6] Cervero R: Public Transport and Sustainable Urbanism: Global Lessons, 2006. UC Berkeley: University of California Transportation Center http://escholarship.org/uc/item/4fp6x44f (2016.07.01.)

[7] Taylor I, Sloman L: Thriving Cities: Integrated Land Use and Transport Planning, 2011. 
http://www.urbantransportgroup.org/system/files/20112706ptegThrivingCitiesRep ortforWebFINAL.pdf (2016.07.01.)

[8] Brogren M, Green A: Hammarby Sjöstad-an interdisciplinary case study of the integration of photovoltaics in a new ecologically sustainable residential area in Stockholm, 2003. Solar Energy Materials \& Solar Cells 75, pp. 761-765 http://dx.doi.org/10.1016/S0927-0248(02)00133-2

[9] Williams J: Can low carbon city experiments transform the development regime? 2016. Futures 77, pp. 80-96. http://dx.doi.org/10.1016/j.futures.2016.02.003

[10] Melia S: On the Road to Sustainability: Transport and Car-free Living in Freiburg 2006. University of the West of England Faculty of the Built Environment www.stevemelia.co.uk/freiburg.doc (2016.07.01.)

[11] Melia, S, Parkhurst G, Barton H: (2011) Carfree, low-car - what's the difference. 2011. World Transport Policy \& Practice, 16/2. pp. 24-28. ISSN:1352-7614

[12] FitzRoy F, Smith I: Public transport demand in Freiburg: why did patronage double in a decade? 1998 Transport Policy 5: pp. 163-173 http://dx.doi.org/10.1016/S0967-070X(98)00024-9

[13] Nobis C: Evaluation des Verkehrskonzeptes im autoreduzierten Stadtteil FreiburgVauban 2003. Informationsnetzwerk „Wohnen plus Mobilität“ - Fachbeitrag Nr. 33 www.mobilitaetsmanagement.nrw.de/cms1/download/fb_33.pdf (2016.07.01.)

[14] Nobis C: The Impact of Car-free Housing Districts on Mobility Behaviour - Case Study. in Beriatos E., Brebbia C.A, Coccossis H, Kungolos A (eds): Conference on Sustainable Planning and Development 2003.WIT, Dorset, pp. 701-720. ISBN: 978-1-85312-985-8

[15] Broaddus A: A Tale of Two Eco-Suburbs in Freiburg, Germany 2010. Journal of the Transportation Research Board 2187 pp. 114-122 http://dx.doi.org/10.3141/2187-15 